\title{
Effect of Rice Straw on Potassium Availability in Illite Containing Soils of Central Plain, Thailand
}

\author{
Timtong DARUNSONTAYA* and Wittaya JINDALUANG
}

Department of Soil Science, Faculty of Agriculture, Kasetsart University, Bangkok 10900, Thailand

\author{
('Corresponding author's e-mail: fagrttd@ku.ac.th)
}

Received: 17 December 2019, Revised: 18 March 2020, Accepted: 19 April 2020

\begin{abstract}
Soil potassium $(\mathrm{K})$ in various forms and the effect of rice straw on soil $\mathrm{K}$ release were studied in lowland soils containing illite clay minerals. Surface soils of 2 Inceptisols and 2 Alfisols were collected to study. Soil samples were incubated for 120 days with rice straw incorporation at different rates $(0,3,125$, 6,250 , and $9,375 \mathrm{~kg} / \mathrm{ha}$ ), and various forms of $\mathrm{K}$ in soils were determined at various times during the period of incubation. The results showed that the readily available $\mathrm{K}$ content (water-soluble $\mathrm{K}+$ exchangeable $\mathrm{K}$ ) of the studied soils increased with the increasing rate of rice straw incorporation. In addition, non-exchangeable $\mathrm{K}$ content also increased with the increasing rate of rice straw incorporation by fixation process for all soils. The maximum increase of water-soluble $\mathrm{K}$ content of the studied soils was observed on the $4^{\text {th }}$ day of incubation for all treatments, corresponding to the decrease of exchangeable $\mathrm{K}$ content at the same time. This result indicated that water-soluble $\mathrm{K}$ and exchangeable $\mathrm{K}$ were in equilibrium. Changes of non-exchangeable $\mathrm{K}$ content during the period of incubation through alternate release and fixation processes were observed monthly. This result suggested that most of the readily available $\mathrm{K}$ enhanced by rice straw incorporation would be beneficial for $\mathrm{K}$ uptake by the plant.
\end{abstract}

Keywords: Forms of potassium, Illite containing paddy soil, Rice straw incorporation, Short-term incubation

\section{Introduction}

Potassium $(\mathrm{K})$ is a major macronutrient which plants usually require in large amount for regular growth and yield [1]. There is an evidence suggesting that lowland soils in Central Plain of Thailand contained a sufficient level of exchangeable K, especially clayey soils. Therefore, $\mathrm{K}$ fertilizer application is not necessarily required for rice cultivation [2]. However, intensive rice cultivation in this region without $\mathrm{K}$ fertilizer application for a long period, in accompanying with continuous crop removal of $\mathrm{K}$ may accelerate decreasing of soil $\mathrm{K}$ content and thus affect negative $\mathrm{K}$ balance in soils. It was also reported that crop removal of $\mathrm{K}$ through rice grains and rice straw ranged from 53.03 and $149.03 \mathrm{~kg}$ $\mathrm{K} / \mathrm{ha} /$ season [3]. Land Development Department [4] stated that many soils in the Central Plain of Thailand had low to medium level of available K. Recently, Thasanon et al. [5] also reported that soils containing high activity clays with clayey-textured soils such as Vertisols in the Central Plain of Thailand had low to medium level of available K, and low K-bearing mineral reserves. Furthermore, according to the farmer's behavior that usually burns rice straw residues after harvest, this action can also accelerate an amount of soil organic matter (OM) and soil K losses. Many studies have been reported that rice straw is a primary important source of $\mathrm{K}$ and a large amount of $\mathrm{K}$ in rice straw residues was lost from burning practice [6,7]. Such evidence suggested that the improvement of soil K fertility status via K fertilizer application and rice straw management should be paid attention to in this region.

Generally, the replenishment of soil K content in the soil system can naturally occur through the $\mathrm{K}$ release process from the wedge zones and interlayer sites of K-bearing minerals structure such as illite or 
http://wjst.wu.ac.th

vermiculite $[1,8]$. Illite clay mineral can fix the available $\mathrm{K}$ from the soil solution into the interlayer structure and this non-exchangeable $\mathrm{K}$ form can also be slowly released and can be transformed to the available $\mathrm{K}$ form [8]. Cox et al. [9] and Darunsontaya et al. [10] suggested that the release of nonexchangeable $\mathrm{K}$ from clay mineral structures was an important source of $\mathrm{K}$ for plant uptake in soil containing illite. Many studies showed that the incorporation of organic residues into the soil may increase $\mathrm{K}$ content in soils [11,12]. In addition, intermediate products from organic residues decomposition such as organic acids may enhance the clay minerals weathering and thus, fixed $\mathrm{K}$ from clay mineral structures could be released $[13,14]$. This research aimed to study the effect of rice straw incorporation on the various forms of $\mathrm{K}$ contents in paddy soils containing illite in the Central Plain, Thailand.

\section{Materials and methods}

Physico-chemical and mineralogical properties analyses

Surface soil (Ap horizon) of 4 representative paddy soils containing illite from the Central Plain of Thailand were collected for the study (Table 1). The studied soils include 2 Inceptisols (Sappaya (Sa) and Ratdhaburi (Rb)) and 2 Alfisols (Manorom (Mn) and Nakhon Pathom (Np)). Parent materials of all studied soils were alluvium and all soils were used for rice cultivation. The physico-chemical properties of soils were analyzed using standard methods [15]. Soil pH was measured in 1:1 soil : water. The particle size distribution was determined by the pipette method [16]. Organic matter (OM) content was determined by the Walkley and Black method [17]. The cation exchange capacity (CEC) was measured with $1 \mathrm{M}$ ammonium acetate $\left(\mathrm{NH}_{4} \mathrm{OAc}\right)$ at $\mathrm{pH} 7.0$ [18]. Total nitrogen was determined by the Kjeldahl method (National Soil Survey Center 1996). Available phosphorus was determined by the Bray II method [19]. Mineral species in clay and silt fractions were identified by scanning with a PANalytical X'Pert ${ }^{3}$ powder X-ray diffractometer using $\mathrm{CoK} \alpha$ radiation. The $\mathrm{K}$ concentration in rice straws samples was analyzed by a digestion mixture of the Kjeldahl method [15].

Table 1 Soil classification and sampling sites.

\begin{tabular}{llc}
\hline Soil series & Classification & \multicolumn{1}{c}{ Location (UTM) } \\
\hline Sapphaya (Sa) & $\begin{array}{l}\text { Fine-loamy, mixed, semiactive, isohyperthermic } \\
\text { Fluventic Endoaquepts }\end{array}$ & 47P 655904N 1630176E \\
Ratdhaburi (Rb) & $\begin{array}{l}\text { Fine-silty, mixed, superactive, isohyperthermic Aeric } \\
\text { Endoaquepts }\end{array}$ & 47P 656475N 1626819E \\
Manorom (Mn) & $\begin{array}{l}\text { Fine, mixed, semiactive, isohyperthermic Aeric } \\
\text { Endoaqualfs } \\
\text { Nakhon Pathom (Np) }\end{array}$ & $\begin{array}{l}\text { Fine, mixed, semiactive, isohyperthermic Aeric } \\
\text { Endoaqualfs }\end{array}$ \\
\hline
\end{tabular}

\section{Determination of soil $\mathbf{K}$ forms}

Forms of $\mathrm{K}$ content were determined by sequential extraction. Firstly, water-soluble K content was determined by shaking a $3 \mathrm{~g}$ soil sample with $30 \mathrm{~mL}$ deionized water for $1 \mathrm{~h}$. The sample was then centrifuged, and the suspension was collected. Secondly, the residual soil sample was then filled with $30 \mathrm{~mL} 1 \mathrm{M} \mathrm{NH}_{4} \mathrm{OAc}$ and was shaken for $1 \mathrm{~h}$; next, the suspension was collected to determine exchangeable $\mathrm{K}$ content [18]. The readily available $\mathrm{K}$ content was calculated from water-soluble $\mathrm{K}$ plus exchangeable $\mathrm{K}$ contents. Thirdly, non-exchangeable $\mathrm{K}$ was determined by boiling the residual soil sample with $30 \mathrm{~mL} 1 \mathrm{M}$ nitric acid $\left(\mathrm{HNO}_{3}\right)$ at $110^{\circ} \mathrm{C}$ for $1 \mathrm{~h}$, followed by washing with $0.1 \mathrm{M} \mathrm{HNO}_{3}$, and making up the final volume to $100 \mathrm{~mL}$ with $0.1 \mathrm{M} \mathrm{HNO}_{3}$ [20]. All extractions were determined in triplicate. The solutions obtained from all steps were analyzed for $\mathrm{K}$ concentration using atomic 
http://wjst.wu.ac.th

adsorbtion spectrophotometry (AAS). The K saturation percentage (\% K sat) was calculated by using the value of readily available $\mathrm{K}$ content (in cmol unit) divided by CEC of the soil and then multiplied by 100 [21].

The study on effect of rice straw incorporation on potassium availability

The study was conducted in a completely randomized design (CRD) with 4 replications. The treatments consisted of 4 rates of rice straws incorporation, $0,3,125,6,250$, and 9,375 $\mathrm{kg} / \mathrm{ha}$. These rates are equal to $0,500,1,000$, and $1,500 \mathrm{~kg} / \mathrm{rai}$, respectively. The average nutrient content of the rice straws used in this experiment were $1.11,0.19$ and $0.91 \% \mathrm{w} / \mathrm{w}$ for total $\mathrm{N}$, total $\mathrm{P}$, and total $\mathrm{K}$, respectively. Each rate of rice straw was finely mixed with $100 \mathrm{~g}$ of the soil sample in a plastic container. Soil samples were then incubated at field capacity (FC) over the experimental period and the level of soil moisture was retained every 2 days by weighting. The samples were then collected by subsampling soils about $5 \mathrm{~g}$ at 2 , $4,7,14,28,42,56,70,90$, and 120 days during the period of incubation. The collecting samples were analyzed for water-soluble $\mathrm{K}$, exchangeable $\mathrm{K}$, and non-exchangeable $\mathrm{K}$ by methods as previously described to determine the transformation of soil K. To determine the significant difference between the means among treatments, Duncan's multiple range test was computed at the 0.05 probability level $(p \leq$ $0.05)$.

Table 2 Physical and chemical properties of studied soils.

\begin{tabular}{ccccc}
\hline Soils series & Sa & Rb & Mn & Np \\
\hline Soil order & Inceptisol & Inceptisol & Alfisol & Alfisol \\
pH (1:1 soil: $\left.\mathrm{H}_{2} \mathrm{O}\right)$ & 5.3 & 5.0 & 5.5 & 6.0 \\
OM $(\mathrm{g} / \mathrm{kg})$ & 41.4 & 21.5 & 24.7 & 33.1 \\
Total $\mathrm{N}(\mathrm{g} / \mathrm{kg})$ & 1.89 & 0.91 & 0.77 & 1.26 \\
Avail. $\mathrm{P}(\mathrm{mg} / \mathrm{kg})$ & 10.3 & 27 & 22 & 23 \\
CEC $(\mathrm{cmol} / \mathrm{kg})$ & 15.5 & 20.8 & 14.9 & 14.4 \\
Sand $(\mathrm{g} / \mathrm{kg})$ & 282 & 151 & 211 & 272 \\
Silt $(\mathrm{g} / \mathrm{kg})$ & 377 & 525 & 520 & 451 \\
Clay $(\mathrm{g} / \mathrm{kg})$ & 341 & 324 & 269 & 277 \\
Textural class & $\mathrm{CL}$ & $\mathrm{SiCL}$ & $\mathrm{SiL}$ & $\mathrm{CL}$ \\
\% K saturation & 2.27 & 1.02 & 1.20 & 1.30 \\
\hline
\end{tabular}

$\mathrm{OM}=$ organic matter; Total $\mathrm{N}=$ total nitrogen; Avail. $\mathrm{P}=$ available $\mathrm{P} ; \mathrm{CEC}=$ cation exchange capacity; $\mathrm{CL}=$ clay loam; $\mathrm{SiCL}=$ silty clay loam; $\mathrm{SiL}=$ silt loam

\section{Results and discussion}

Physico-chemical and mineralogical properties of studied soils

According to Thasanon et al. [5], Sa and Rb soil series were classified as Inceptisols whereas Mn and $\mathrm{Np}$ were Alfisols. Soil textures ranged from silt loam to clay loam (Table 2). However, the higher clay content was found in Inceptisols ( $\mathrm{Sa}$ and $\mathrm{Rb}$ ) in comparison to Alfisols ( $\mathrm{Mn}$ and $\mathrm{Np}$ ). Soil $\mathrm{pH}$ ranged from strongly acid to moderately acid ( $\mathrm{pH} 5.3$ to 6.0). Organic matter contents of the studied soils were medium to moderately high with very low to low total $\mathrm{N}$ contents. Available phosphorus of the studied soils was medium to moderately high. All soils had medium to high CEC. This result may contribute to the important role of soil OM, besides the type of clay minerals that affect the CEC of the studied soils. According to the range of $\% \mathrm{~K}$ saturation required for rice growing as suggested by Dobermann and 
http://wjst.wu.ac.th

Fairhurst [22], \% K saturation below $1.5 \%$ indicates low $\mathrm{K}$ fertility status of the soil, and $\mathrm{K}$ fertilization is needed. The result of this study showed that all soil samples, before incubation study, except Sa had low $\% \mathrm{~K}$ saturation ranging from $1.02-1.30 \%$. Such a result indicated that only a small proportion of the CEC of studied soils was occupied by $\mathrm{K}^{+}$(Table 2) [21]. Therefore, this evidence suggested that without $\mathrm{K}$ fertilizer management, $\mathrm{K}$ deficiency for rice cultivation in this region may arise as an important risk.

The mineralogy of clay fractions for all studied soils consisted of kaolinite, illite, and smectite in a similar proportion (Table 3). This result indicated that the studied soils had low development due to the presence of weatherable minerals. In addition, small amounts of interstratified clay minerals and quartz were found in the clay fractions of studied soils. These results were consistent with the study of Yoothong et al. [23] who reported that the clay mineralogy of lowland soils in the Central Plain of Thailand was mixed mineralogy with a trace number of interstratified clays. The result showed that quartz was the dominant mineral in silt fractions and a small amount of $10 \AA$ mineral was also found in all soil series. According to the mineral composition of silt and clay fractions, these soils contained K-bearing minerals that could release $\mathrm{K}$ from the mineral structures and thus, available for plant uptake in the long term $[9,10,24]$.

Table 3 Mineral composition in silt and clay fractions of studied soils.

\begin{tabular}{|c|c|c|c|c|c|c|c|c|c|c|}
\hline \multirow{2}{*}{ Soils } & \multicolumn{5}{|c|}{ Clay fraction } & \multicolumn{5}{|c|}{ Silt fraction } \\
\hline & Kao & Ill & Smc & Int 10 and $14 \AA$ & Qtz & Qtz & $7 \AA$ clay & $10 \AA$ clay & Mc & $\mathbf{A b}$ \\
\hline $\mathrm{Sa}$ & $\mathrm{xx}$ & $\mathrm{xx}$ & $\mathrm{xx}$ & $\operatorname{tr}$ & - & $\operatorname{xxxx}$ & $\operatorname{tr}$ & $\operatorname{tr}$ & tr. & - \\
\hline $\mathrm{Rb}$ & $\mathrm{xx}$ & $\mathrm{xx}$ & $\mathrm{xx}$ & - & - & $\operatorname{xxxx}$ & $\operatorname{tr}$ & $\operatorname{tr}$ & $\operatorname{tr}$ & $\operatorname{tr}$ \\
\hline $\mathrm{Mn}$ & $\mathrm{xx}$ & $\mathrm{xx}$ & $\mathrm{xx}$ & - & $\operatorname{tr}$ & $\operatorname{xxxx}$ & - & $\operatorname{tr}$ & $\operatorname{tr}$ & $\operatorname{tr}$ \\
\hline $\mathrm{Np}$ & $\mathrm{xx}$ & $\mathrm{xx}$ & $\mathrm{xx}$ & - & - & $\mathrm{xxxx}$ & $\operatorname{tr}$ & $\operatorname{tr}$ & $\operatorname{tr}$ & $\operatorname{tr}$ \\
\hline
\end{tabular}

Kao = Kaolinite; Ill = Illite; Smc = Smectite; Int 10 and $14 \AA=$ interstratified clay minerals; Qtz = Quartz; $\mathrm{Mc}=$ microcline; $\mathrm{Ab}=$ Albite; $\mathrm{tr}=\operatorname{trace}(<5 \%), \mathrm{x}=$ small $(5-20 \%), \mathrm{xx}=$ moderate $(20-40 \%), \mathrm{xxx}=$ large $(40-60 \%), \operatorname{xxxx}=$ dominant $(>60 \%) .(-)=$ not detected.

\section{Effect of rice straw incorporation on soil potassium contents in various forms}

The result showed that without rice straw incorporation (control treatment), almost all soil series had medium readily available $\mathrm{K}$ (water-soluble $\mathrm{K}+$ exchangeable $\mathrm{K}$ ) contents $(60-90 \mathrm{mg} / \mathrm{kg}$ ). Only Sa soil series showed a high level (>120 mg/kg) of readily available K (Table 4) [2]. This result suggested that Sa soil series may contain a sufficient amount of available $\mathrm{K}$ for rice productions, whereas almost soil series may need practices that improve $\mathrm{K}$ fertility status. However, water-soluble $\mathrm{K}$ and exchangeable $\mathrm{K}$ are the easiest forms of $\mathrm{K}$ that could be leached away from the root zone, especially those soils from Alfisols (Mn and Np). Accordingly, Thasanon et al. [5] reported that water-soluble $\mathrm{K}$ and exchangeable $\mathrm{K}$ of Alfisols in the Central Plain of Thailand were observed to increase from the surface soils to the depth of $100 \mathrm{~cm}$ below soil surface, indicating translocation of $\mathrm{K}^{+}$through the leaching process. Therefore, the result supported that efficient $\mathrm{K}$ management is still required to maintain $\mathrm{K}$ fertility status in these soils. According to Rao et al. [25], the studied soils contained medium to high (239- $605 \mathrm{mg} / \mathrm{kg})$ non-exchangeable $\mathrm{K}$ contents for the control treatment (Table 4). This result was consistent to the mineral composition in silt and clay fractions of studied soils that comprised with a moderate amount (20 - $40 \%$ ) of K-bearing minerals such as illite, and microcline (Table 3). 
http://wjst.wu.ac.th

Table 4 Effect of rice straws on K content in various forms of 4 studied soils at 120 days after incubation.

\begin{tabular}{|c|c|c|c|c|c|c|c|c|c|c|c|c|c|c|c|c|}
\hline \multirow{3}{*}{ Treatment } & \multicolumn{4}{|c|}{ Sa } & \multicolumn{4}{|c|}{$\mathbf{R b}$} & \multicolumn{4}{|c|}{ Mn } & \multicolumn{4}{|c|}{ Np } \\
\hline & WK & ExK & NEK & Av.K & WK & ExK & NEK & Av.K & WK & ExK & NEK & Av.K & WK & ExK & NEK & Av.K \\
\hline & \multicolumn{16}{|c|}{ 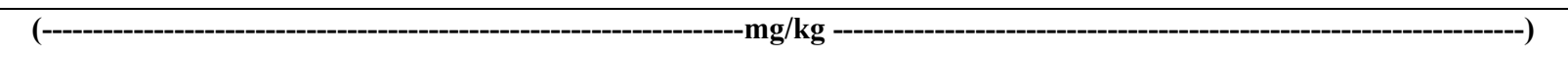 } \\
\hline $\mathrm{T} 1$ & $29^{\mathrm{b}}$ & $104^{\mathrm{c}}$ & $583^{\mathrm{c}}$ & $133^{\mathrm{d}}$ & $20^{\mathrm{b}}$ & $63^{\mathrm{d}}$ & $550^{\mathrm{b}}$ & $83^{\mathrm{d}}$ & $21^{\mathrm{c}}$ & $50^{\mathrm{c}}$ & $239^{\mathrm{c}}$ & $70^{\mathrm{c}}$ & $10^{\mathrm{c}}$ & $63^{b}$ & $440^{\mathrm{c}}$ & $73^{d}$ \\
\hline $\mathrm{T} 2$ & $31^{\mathrm{b}}$ & $115^{\mathrm{b}}$ & $633^{b c}$ & $146^{\mathrm{c}}$ & $31^{\mathrm{a}}$ & $76^{\mathrm{c}}$ & $576^{\mathrm{b}}$ & $106^{\mathrm{c}}$ & $29^{\mathrm{b}}$ & $71^{\mathrm{b}}$ & $243^{b c}$ & $100^{\mathrm{b}}$ & $14^{\mathrm{b}}$ & $72^{b}$ & $460^{\mathrm{bc}}$ & $86^{c}$ \\
\hline $\mathrm{T} 3$ & $36^{\mathrm{b}}$ & $124^{\mathrm{b}}$ & $660^{\mathrm{ab}}$ & $161^{\mathrm{b}}$ & $33^{\mathrm{a}}$ & $95^{\mathrm{b}}$ & $638^{\mathrm{a}}$ & $128^{\mathrm{b}}$ & $32^{\mathrm{ab}}$ & $80^{\mathrm{b}}$ & $265^{\mathrm{b}}$ & $112^{\mathrm{b}}$ & $21^{\mathrm{a}}$ & $103^{\mathrm{a}}$ & $474^{\mathrm{ab}}$ & $124^{\mathrm{b}}$ \\
\hline $\mathrm{T} 4$ & $45^{\mathrm{a}}$ & $152^{\mathrm{a}}$ & $674^{\mathrm{a}}$ & $198^{\mathrm{a}}$ & $36^{\mathrm{a}}$ & $114^{\mathrm{a}}$ & $674^{\mathrm{a}}$ & $149^{\mathrm{a}}$ & $38^{\mathrm{a}}$ & $95^{\mathrm{a}}$ & $294^{\mathrm{a}}$ & $133^{\mathrm{a}}$ & $25^{\mathrm{a}}$ & $111^{\mathrm{a}}$ & $479^{\mathrm{a}}$ & $136^{\mathrm{a}}$ \\
\hline F-Test & $*$ & $*$ & $*$ & $*$ & * & $*$ & $*$ & $*$ & $*$ & $*$ & $*$ & $*$ & $*$ & $*$ & $*$ & * \\
\hline$\%$ C.V. & 7.6 & 3.2 & 2.1 & 2.7 & 8.3 & 4.7 & 3.7 & 4.0 & 8.2 & 7.8 & 3.4 & 6.8 & 7.0 & 4.7 & 1.3 & 4.6 \\
\hline
\end{tabular}

$\mathrm{WK}=$ water-soluble $\mathrm{K}$; ExK = exchangeable $\mathrm{K}$; NEK = non-exchangeable $\mathrm{K}$; Av.K = readily available $\mathrm{K}$ $\mathrm{ns}=$ not significant; $*$ significantly different at 0.05 probability levels; means with different lowercase superscript letters within a column indicate a significant difference according to Duncan's multiple range test at $\mathrm{p} \leq 0.05$.

$\mathrm{T} 1($ Control $)=$ no rice straw incorporation; $\mathrm{T} 2=$ rice straw incorporation at $3,125 \mathrm{~kg} / \mathrm{ha} ; \mathrm{T} 3=$ rice straw incorporation at $6,250 \mathrm{~kg} / \mathrm{ha} ; \mathrm{T} 4=$ rice straw incorporation at $9,375 \mathrm{~kg} / \mathrm{ha}$.

The effect of rice straw incorporation on the various forms of $\mathrm{K}$ contents at 120 days after incubation showed that water-soluble $\mathrm{K}$ contents of the studied soils significantly increased with increasing rate of rice straw incorporation $(14-45 \mathrm{mg} / \mathrm{kg})$ in comparison to control treatment $(10-29$ $\mathrm{mg} / \mathrm{kg}$ ) (Table 4). The maximum increase of water-soluble $\mathrm{K}$ content was observed in rice straw incorporation at the rate of $9,375 \mathrm{~kg} / \mathrm{ha}$ (T4) $(25$ to $45 \mathrm{mg} / \mathrm{kg}$ or $55.2-150 \%$ increased from control treatment). This result indicated that water-soluble $\mathrm{K}$ may release from decomposed-rice straw residuals during the period of incubation [7]. In addition, Kaur and Benipal [12] reported that the rice straw incorporation improved water holding capacity of soils, and thus may enhance $\mathrm{K}^{+}$adsorption from the soil solution. Likewise, water-soluble $\mathrm{K}$, exchangeable $\mathrm{K}$ contents of the studied soils significantly increased with increasing rate of rice straw incorporation $(71-152 \mathrm{mg} / \mathrm{kg})$ in comparison to control treatment (50 - $104 \mathrm{mg} / \mathrm{kg}$ ). The maximum increase of exchangeable $\mathrm{K}$ content was observed in rice straw incorporation at the rate of $9,375 \mathrm{~kg} / \mathrm{ha}$ (T4) $(95$ to $152 \mathrm{mg} / \mathrm{kg}$ or $46.2-90 \%$ increased from control treatment). The result was consistent with the study of Yadav et al. [11] who reported that rice straw incorporation increased a greater amount of exchangeable $\mathrm{K}$ than inorganic fertilizer application. Singh et al. [26] reported that incorporation of organic residuals could improve CEC of the soil, and thus enhance $\mathrm{K}^{+}$adsorption on the exchange sites. The result of this study suggested that rice straw is the primary important $\mathrm{K}$ resource for plant uptake, and incorporation of rice straw significantly improved the readily available $\mathrm{K}$ content for all studied soils.

Non-exchangeable $\mathrm{K}$ contents of the studied soils also significantly increased with the increasing rate of rice straw incorporation ( 243 to $674 \mathrm{mg} / \mathrm{kg}$ ) in comparison to control treatment (239 to $583 \mathrm{mg} / \mathrm{kg}$ ) (Table 4). The maximum increase of non-exchangeable $\mathrm{K}$ content was observed in rice straw incorporation at the rate of $9,375 \mathrm{~kg} / \mathrm{ha}$ (T4) $(294$ to $674 \mathrm{mg} / \mathrm{kg}$ or $8.9-23 \%$ increased from control treatment). In general, when $\mathrm{K}$ in soil solution (water-soluble $\mathrm{K}$ ) increases and exchange sites of clay minerals saturate with exchangeable $\mathrm{K}$, these forms of $\mathrm{K}$ will be consequently fixed into wedge zones and interlayer sites of 2:1 clay minerals, therefore non-exchangeable $\mathrm{K}$ increases. On the other hand, when $\mathrm{K}$ in soil solution decreases and exchange sites of clay minerals occupy by a small amount of exchangeable $\mathrm{K}$, non-exchangeable $\mathrm{K}$ will be consequently released to equilibrate the soil $\mathrm{K}$ system $[1,8]$. Therefore, with increasing readily available $\mathrm{K}$ content from rice straw incorporation, $\mathrm{K}$ fixation may take places for all studied soils due to exchange sites of clay minerals were progressively saturated by $\mathrm{K}^{+}$, and thus 
http://wjst.wu.ac.th

excessive readily available $\mathrm{K}$ may be consequently fixed into wedge zones and interlayer sites of 2:1 clay minerals such as illite and smectite.

Sa

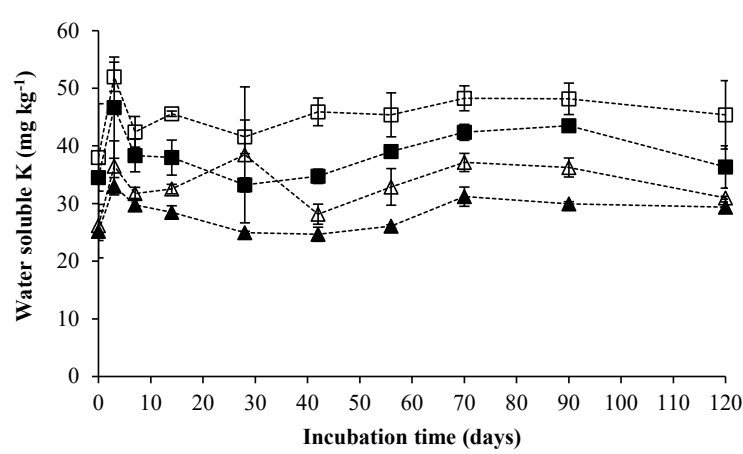

Mn

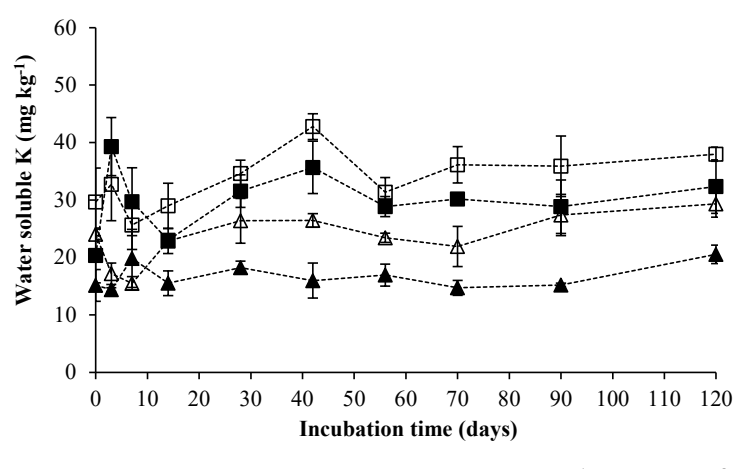

$\mathbf{R b}$

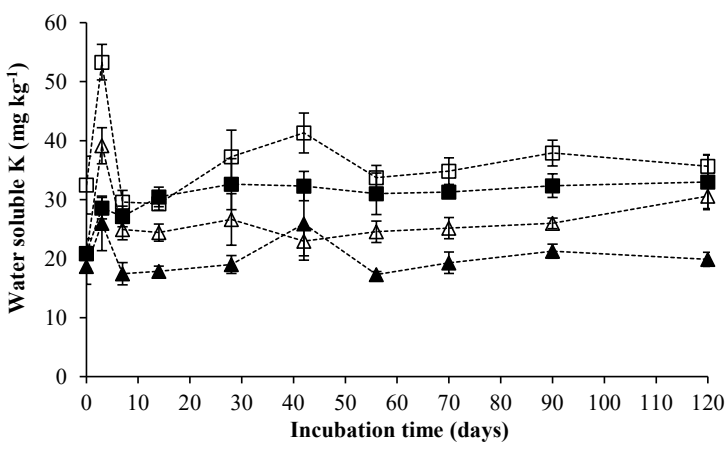

Np

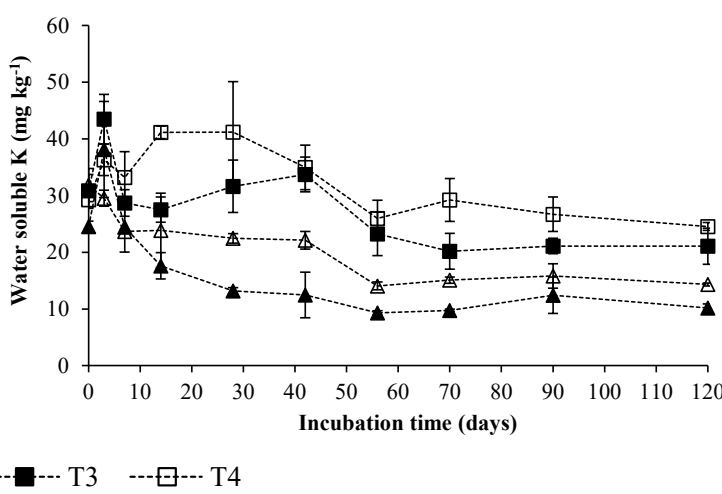

Figure 1 Effect of rice straw incorporation on water-soluble K content of studied soils ( $\mathrm{Sa}, \mathrm{Rb}, \mathrm{Mn}, \mathrm{Np}$ ) during 120 days of incubation. T1 (Control) = no rice straw incorporation; T2 = rice straw incorporation at $3,125 \mathrm{~kg} / \mathrm{ha} ; \mathrm{T} 3=$ rice straw incorporation at $6,250 \mathrm{~kg} / \mathrm{ha}$; T4 = rice straw incorporation at $9,375 \mathrm{~kg} / \mathrm{ha}$.

Effect of rice straw incorporation on soil potassium dynamics

Considering to soil $\mathrm{K}$ dynamic during 120 days of incubation, the reverse interaction between water-soluble $\mathrm{K}$ and exchangeable $\mathrm{K}$ was observed throughout the incubation period (Figures 1 and 2). While water-soluble $\mathrm{K}$ content increased, the exchangeable $\mathrm{K}$ content decreased at the same time. This result indicated that water-soluble $\mathrm{K}$ and exchangeable $\mathrm{K}$ in these soils were in equilibrium. In this study, water-soluble $\mathrm{K}$ had the maximum increase on the $4^{\text {th }}$ day of incubation after rice straw incorporation, corresponding to the decrease of exchangeable $\mathrm{K}$ at the same time. This result was similar to that reported by $\mathrm{Li}$ et al. [7] that a rapid decomposition of rice straw was taken place from 0 to 60 days, but $90 \%$ of total $\mathrm{K}$ was released by the $3^{\text {rd }}$ day of the study. The result of the present study revealed that water-soluble $\mathrm{K}$ is rapidly released from rice straw decomposition and thus could be available for plant uptake within a few days after rice straw incorporation. Li et al. [7] also concluded that incorporation of crop residues could enhance the water holding capacity of the soil and a large amount of $\mathrm{K}^{+}$in an aqueous solution could indirectly preserve by rice straw during the initial decomposition period. Therefore, the incorporation of rice straw not only increased readily available $\mathrm{K}$ content but also prevented $\mathrm{K}$ leaching from $\mathrm{K}$ fertilization. Changes of non-exchangeable $\mathrm{K}$ content during the period of incubation through alternate release and fixation processes were also observed, but this $\mathrm{K}$ form took approximately 30 days 
cycle for its transformation (Figure 3). This result indicated that $\mathrm{K}$ release and fixation in these illitecontaining soils slowly occurred in comparison to the release of readily available $\mathrm{K}$ from rice straw decomposition. Therefore, most of the readily available $\mathrm{K}$ content enhanced by rice straw incorporation in these soils would be beneficial for K uptake by the plant.

Sa

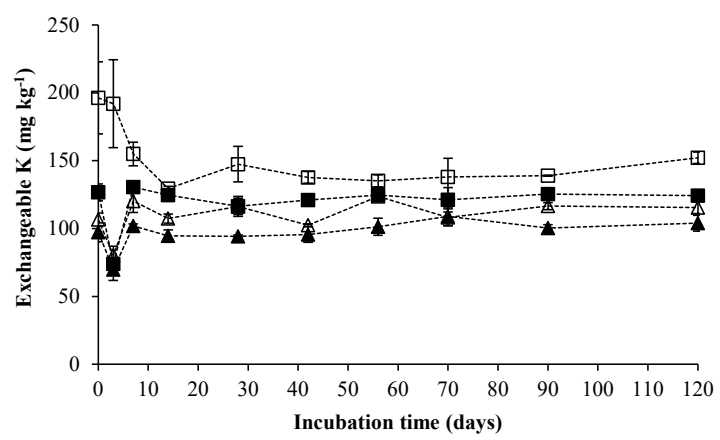

Mn

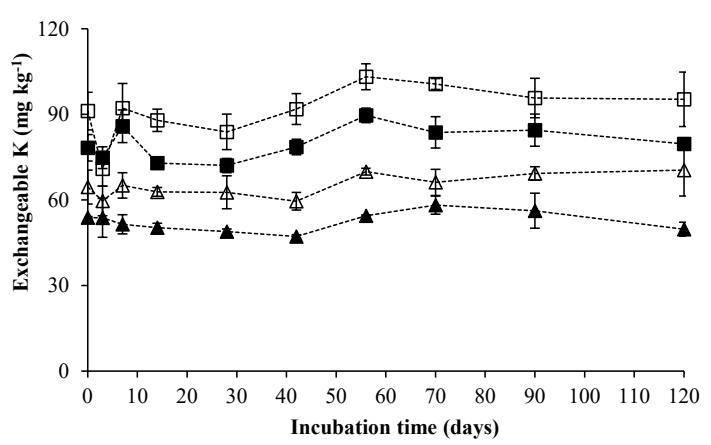

$\mathbf{R b}$

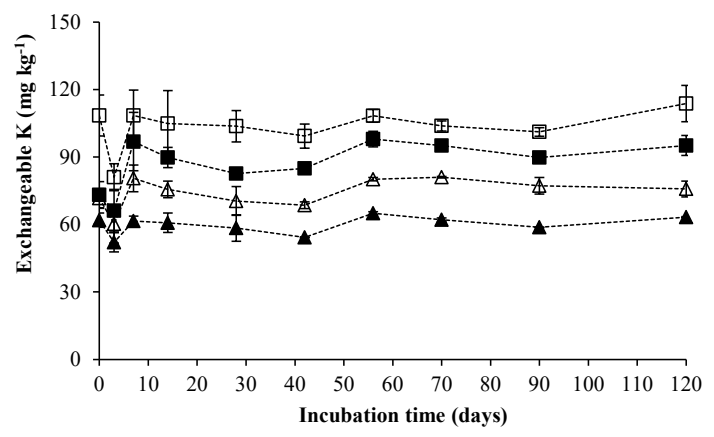

Np

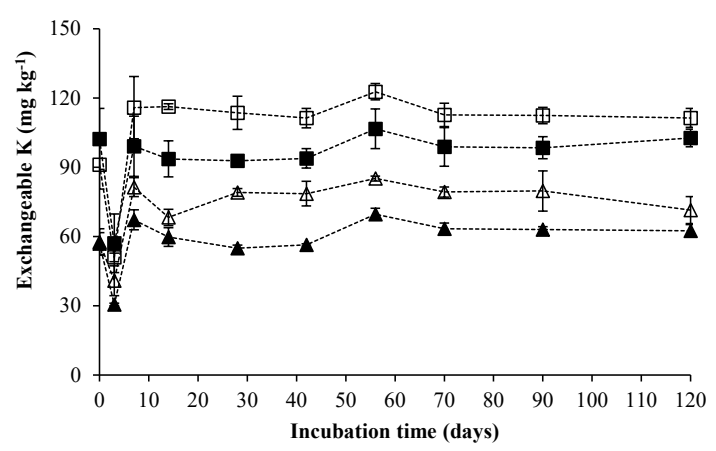

T3 $\quad---\boxminus--\mathrm{T} 4$

Figure 2 Effect of rice straws on exchangeable $\mathrm{K}$ content of studied soils ( $\mathrm{Sa}, \mathrm{Rb}, \mathrm{Mn}, \mathrm{Np}$ ) during 120 days of incubation. $\mathrm{T} 1$ (Control) $=$ no rice straw incorporation; $\mathrm{T} 2=$ rice straw incorporation at 3,125 $\mathrm{kg} / \mathrm{ha} ; \mathrm{T} 3=$ rice straw incorporation at $6,250 \mathrm{~kg} / \mathrm{ha} ; \mathrm{T} 4=$ rice straw incorporation at $9,375 \mathrm{~kg} / \mathrm{ha}$. 
Sa

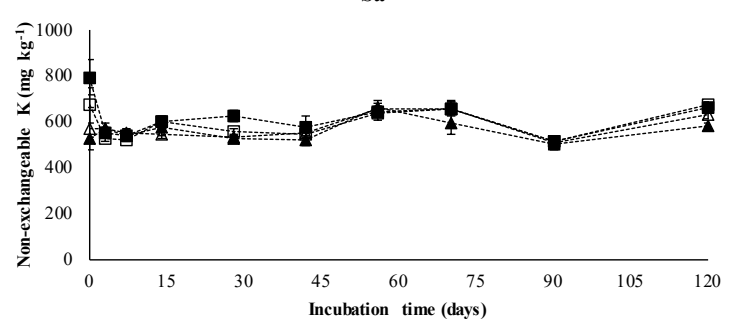

Mn

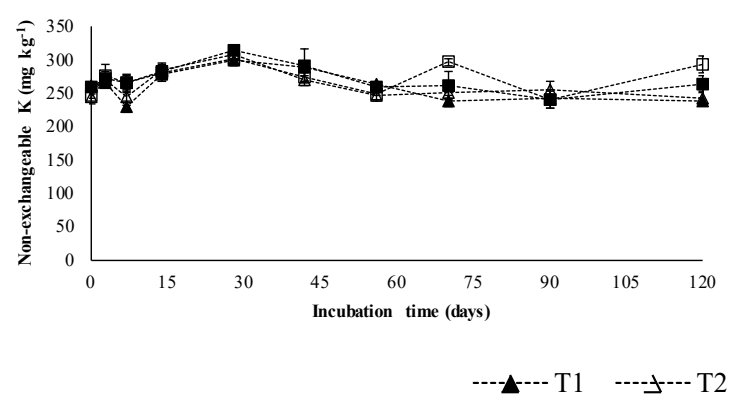

$\mathbf{R b}$

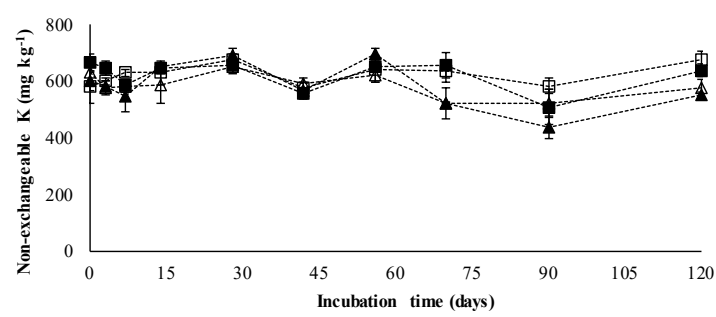

Np

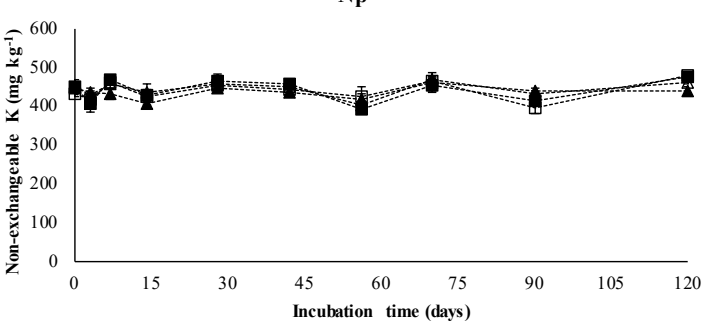

T3 ---曰-- T4

Figure 3 Effect of rice straws on non-exchangeable K content of studied soils ( $\mathrm{Sa}, \mathrm{Rb}, \mathrm{Mn}, \mathrm{Np}$ ) during 120 days of incubation. $\mathrm{T} 1(\mathrm{Control})=$ no rice straw incorporation; T2 = rice straw incorporation at 3,125 $\mathrm{kg} / \mathrm{ha} ; \mathrm{T} 3=$ rice straw incorporation at $6,250 \mathrm{~kg} / \mathrm{ha} ; \mathrm{T} 4=$ rice straw incorporation at 9,375 $\mathrm{kg} / \mathrm{ha}$.

\section{Conclusions}

The result of this study showed that rice straw incorporation had a beneficial effect on $\mathrm{K}$ availability in these illite-containing soils. The readily available $\mathrm{K}$ (water-soluble $\mathrm{K}+$ exchangeable $\mathrm{K}$ ) highly increased with the increasing rate of rice straw incorporation, ranging from $48.9-90 \%$ in comparison to control treatment within a few days after rice straw incorporation. The non-exchangeable $\mathrm{K}$ content of the studied soils also increased in a small proportion $(8.9-23 \%)$ with the increasing rate of rice straw incorporation. However, this $\mathrm{K}$ form took a much longer time for its transformation than that of readily available $\mathrm{K}$ through alternate release and fixation processes. Therefore, this study suggested that most of readily available $\mathrm{K}$ enhanced by rice straw incorporation would efficiently improve $\mathrm{K}$ availability for plant uptake in the short term, while $\mathrm{K}$ release from wedge zones and interlayers of illite structure may occasionally occur and may be available for plant uptake in the long term depending on the equilibrium of soil K system.

\section{Acknowledgments}

This research is supported by Kasetsart University Research and Development Institute (KURDI), Thailand. The assistance of Miss Pitchakorn Suttanukool, the staff of the Soil Science Department, and the Office of Science for Land Development, Thailand is gratefully acknowledged. 
http://wjst.wu.ac.th

\section{References}

[1] JL Havlin, JD Beaton, SL Tisdale and WL Nelson. Soil Fertility and Fertilizers: An Introduction to Nutrient Management. Upper Saddle River, New Jersey, 2005, p. 199-218.

[2] Division of Rice Research Development, Available at: http://www.ricethailand.go.th/Rkb/manual /index.php-file=content.php\&id=47.htm, accessed September 2019.

[3] KN Sukristiyonubowo and M Sarwani. Nitrogen, phosphorus and potassium removal by rice harvest product planted in newly opened wetland rice. Int. Res. J. Plant Sci. 2012; 3, 63-8.

[4] Land Development Department. State of Soil and Land Resources of Thailand (in Thai). Land Development Department, Ministry of Agriculture and Cooperatives, Bangkok, 2015, p. 304.

[5] P Thasanon, T Darunsontaya, W Jindaluang and C Khongkaew. Forms of potassium in paddy soils, Central Plain of Thailand (in Thai). Songklanakarin J. Plant Sci. 2018; 5, 58-66.

[6] B Mishra, PK Sharma and KF Bronson. Decomposition of rice straw and mineralization of carbon, nitrogen, phosphorus and potassium in wheat field soil in Western Uttar Pradesh. J. Indian Soc. Soil Sci. 2001; 49, 419-24.

[7] J Li, J Lu, X Li, T Ren, R Cong and L Zhou. Dynamics of potassium release and adsorption on rice straw residue. PLoS One 2014; 9, e90440.

[8] DL Sparks. Potassium dynamics in soils. Adv. Soil Sci. 1987; 6, 1-63.

[9] AE Cox, BC Joern, SM Brouder and D Gao. Plant-available potassium assessment with a modified sodium tetraphenylboron method. Soil Sci. Soc. Am. J. 1999; 63, 902-11.

[10] T Darunsontaya, A Suddhiprakarn, I Kheoruenromne, N Prakongkep and RJ Gilkes. The forms and availability to plants of soil potassium as related to mineralogy for upland Oxisols and Ultisols from Thailand. Geoderma 2012; 170, 11-24.

[11] SK Yadav, DK Benbi and AS Toor. Effect of long-term application of rice straw, farmyard manure and inorgnic fertilizer on potassium dynamics in soil. Arch. Agron. Soil Sci. 2019; 65, 374-84.

[12] N Kaur and DS Benipal. Effect of crop residue and farmyard manure on K forms on soils of long term fertility experiment. Indian J. Crop Sci. 2006; 1, 161-4.

[13] KG Cassman, DC Olk, SM Broader and BA Roberts. The influence of moisture regime, organic matter and root ecophysiology on availability and acquisition of Potassium. Implication for tropical lowland rice. In: Proceedings of the $24^{\text {th }}$ Colloquium of the International Potash Institute on Potassium in Asia, Chiang Mai, Thailand. 1995, p. 135-56.

[14] AG Wihardjaka, GJD Kirk, S Abdulrachman and CP Mamank. Potassium balance in rain-fed lowland rice on a light textured soil. Field Crops Res. 1999; 64, 237-47.

[15] National Soil Survey Center. Soil Survey Laboratory Method Manual; Soil Survey Investigation. Report No. 42. National Resources Conservation Service, United States Department of Agriculture, 1996, p. 700

[16] GW Gee and JW Bauder. Particle-size analysis. In: A Klute (Ed.). Methods of soil analysis: Part 1Physical and mineralogical methods. American Society of Agronomy, Madison, Wisconsin, 1986, p. 383-411.

[17] A Walkley and IA Black. An examination of digestion method for determining soil organic matter and a proposed modification of the chroma acid titration method. Soil Sci. 1934; 37, 29-38.

[18] GW Thomas. Exchangeable cations. In: AL Page (Ed.). Methods of Soil Analysis: Part 2. Chemical and Microbiological Properties Properties. $2^{\text {nd }}$ ed. American Society of Agronomy, Madison, Wisconsin, 1982, p. 159-65.

[19] RH Bray and LT Kurtz. Determination of total, organic, and available forms of phosphorus in soils. Soil Sci. 1945; 59, 39-46.

[20] PE Pratt. Potassium. In: CA Black (Ed.). Methods of Soil Analysis: Part 2 Chemical and Microbiological Properties. American Society of Agronomy, Madison, Wisconsin, 1965, p. 102331.

[21] H Mutscher. Measurement and Assessment of Soil Potassium. International Potash Institute, Basel, 1995 , p. 39. 
http://wjst.wu.ac.th

[22] A Dobermann and T Fairhurst. Rice: Nutrient disorders \& nutrient management. Potash \& Phosphate Institute (PPI), Potash \& Phosphate Institute of Canada (PPIC) and International Rice Research Institute, Philippine, 2000, p. 191.

[23] K Yoothong, L Moncharoen, P Vijarnson and H Eswaran. Clay mineralogy of Thai soils. Appl. Clay Sci. 1997; 11, 357-71.

[24] T Darunsontaya, A Suddhiprakarn, I Kheoruenromne and RJ Gilkes. The kinetics of potassium release to sodium tetraphenylboron solution from the clay fraction of highly weathered soils. Appl. Clay Sci. 2010; 50, 376-85.

[25] CS Rao, AS Rao, KV Rao, B Venkateswarlu and AK Singh. Categorisation of districts based on nonexchangeable potassium: Implications in efficient $\mathrm{K}$ fertility management in Indian agriculture. Indian J. Fert. 2010; 6, 40-54.

[26] M Singh, VP Singh and KS Reddy. Effect of integrated use of fertilizer nitrogen and farmyard manure or green manure on transformation of $\mathrm{N}, \mathrm{K}$ and $\mathrm{S}$ and productivity of rice-wheat system on a Vertisols. J. Indian Soc. Soil Sci. 2001; 49, 430-5. 